\title{
PERLAWANAN DAN PEMBEBASAN KOLONIALISME PADA TAREKAT QADIRIYAH WA NAQSYABANDIYAH (1888-1903)
}

\author{
Reni Dian Anggraini ${ }^{1}$ \\ ${ }^{1}$ Institut Islam Negeri (LAIN) Bukittinggi, Indonesia, e-mail: renidian1997@gmail.com

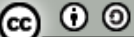 \\ (C)2020 by the authors. Submitted for possible open access publication under the terms and conditions \\ of the Creative Commons Attribution (CC-BY-SA) license (https://creativecommons.org/licenses/by-sa/4.0/) \\ do) $D O I: \underline{\text { http://dx.doi.org/10.30983/it.v4i2.3346 }}$

\begin{tabular}{|c|}
\hline Diterima: 13 Juli 2020 \\
\hline
\end{tabular}

\begin{abstract}
This paper explains and describes how tarekat and Sufi political resistance as agents of change and liberation from colonialism in the Qadiriyah wa Naqsyabandiyah order. A Sufi is not a person who only dwells on spirituality, but also with social and political problems, such as resistance and rebellion against colonial rule. In carrying out this resistance, it cannot be separated from the encouragement of the Qadiriyah wa Naqsyabandiyah order. It was the tarekat that played an active role in defending colonialism, which criticized society and the oppression that had been perpetrated by colonialism. In carrying out his defense action, the Sufi order of the Qadiriyah wa Naqsyabandiyah order taught knowledge to his students to fight against colonialism. Fighting colonialism was not easy to go through. It even claimed many lives. Seeing this reality did not diminish the spirit of the tarekat in carrying out their actions as defenders of society in colonialism over colonialism. In this discussion, the authors use the library method by using various related sources in books, journals, and articles. Thus this paper attempts to unravel the problems of Sufism and political resistance and Sufi roles in liberation from colonialism pioneered by the Qadiriyah wa Naqsyabandiyah tarekat.
\end{abstract}

Keywords: Sufi; Politics; Liberation and freedom.

\begin{abstract}
Abstrak
Tulisan ini menjelaskan dan menguraikan tentang bagaimana peran tarekat dalam perlawanan politik, sufi sebagai agen perubahan dan pembebasan dari kolonialisme dalam tarekat Qadiriyah wa Naqsyabandiyah. Seorang sufi bukanlah orang yang hanya berkutat pada spiritualitas, tetapi juga dengan persoalan sosial dan politik, seperti perlawanan dan pemberontakan terhadap penjajahan kolonial. Dalam melakukan perlawanan tersebut tidak bisa terelepas dari dorongan para tarekat Qadiriyah wa Naqsyabandiyah. Tarekatlah yang sangat berperan aktif dalam melakukan pembelaan dari penjajahan kolonialisme yang mengecam masyarakat dan ketertindasan yang telah dilakukan oleh para kolonialisme. Dalam menjalankan asksi pembelaannya, sufi tarekat Qadiriyah wa Naqsyabandiyah mengajarkan ilmu kepada muridnya untuk berjibad melawan penjajahan. Dalam melawan kolonialisme tidak mudah untuk dilalui, babkan banyak memakan korban jiwa. Melihat realitas tersebut tidak memudarkan semangat para tarekat dalam menjalankan aksinya sebagai pembela masyarakat dalam penjajahan atas kolonialisme. Dalam pembahasan ini penulis menggunakan metode kepustakaan dengan menggunakan berbagai sumber yang terkait berupa buku, jurnal serta artikel. Dengan begitu tulisan ini mencoba untuk menjelaskan bagaimana tasawuf dan perlawanan politik, serta sufi berperan dalam pembebasan dari kolonialisme yang dipelopori oleh tarekat Qadiriyah wa Naqsyabandiyah.
\end{abstract}

Kata Kunci: Sufi; Politik; Perlawanan dan pembebasan.

\section{Latar Belakang}

Pada dasarnya ajaran dalam Islam dapat dikategorikan dalam tiga aspek: Pertama, Iman, kedua Islam, ketiga Ihsan. Dalam ajaran Islam yang terdapat pada tatanan ibadah atau hubungan manusia dengan Tuhan juga dibagi dalam tiga tingkat yaitu: tingkat pertama Syari'at, tingakat kedua tarekat, serta tingkat

1 Ma'mun Mu'min, “Sejarah Perkembangan Pendidikan Tasawuf (Studi Tariqah Qadiriyah wa ketiga hakekat. Pada hal tersebut tarekat itu sama maksudnya dengan syari'at yaitu suatu cara atau jalan untuk mencapai hakekat kepada Tuhan. ${ }^{1}$

Manusia dapat dikatakan makhluk politik (zoom politicon), hakikat dalam kehidupannya adalah yang saling berinteraksi antara dua orang 
atau lebih serta bersosial politik dengan tujuan untuk memenuhi kehidupan sehari-hari. Dengan begitu zoom politicon dalam pandangan Plato manusia secara inidividu tersebut merupakan bagian terkecil pada sebuah Negara. Sehingga pada dasarnya manusia disebut dengan room politicon tersebut membutuhkan tempat atau sebuah wadah serta organisasi untuk mengeluarkan pemikirannya serta keinginan untuk berpolitik tersebut. ${ }^{2}$

Menjadi seorang sufi bagi sebagian kalangan, berarti sikap apatis terhadap hak-hak yang bersifat duniawi, termasuk bidang politik. Zubud, uzlah dan sebagainya merupakan beberapa doktrin tasawuf menjadikan kehidupan sufi terlihat ekslusif dan asosial, sehingga dengan doktrin tersebut para sufi lebih memakai cara uথlah dari pada berkecimpung dalam kekacauan kehidupan ini.

Di era kontemporer, tasawuf serta politik dapat dikatakan dua hal yang paradoks. Dunia politik yang kadang lebih cendrung sekuler bahkan materialistik menjadi alasan mendasar bagi para sufi untuk menjauhinya. Sementara itu, banyak politis memandang bahwa kehidupan sufi hanya akan mengekang kreativitas dan ambisi politik. ${ }^{3}$

Padahal dalam sejarah kolonialisme Nusantara, yang sangat berperan penting dalam perlawanan ini adalah para tarekat yang mengalami perkembangan yang sangat luar biasa seperti: tarekat Naqsyabandiyah, tarekat Qadiriiyah wa Naqsyabandiyah dan tarekattarekat lainnya. Perjuangan para tokoh sufi tarekat tersebut tidak dapat terlepas dari usaha

${ }^{2}$ Kiki Mikail, "Politik dan Perempuan: Perjuangan Politik Perempuan di Iran Pasca Revolusi Islam 1979," ADDIN 9, no. 2 (2015): 254-55, https://doi.org/10.21043/addin.v9i2.615.

${ }^{3}$ Suhayib Suhayib, "Pemikiran Tasawuf Said Nursi dalam Pemberdayaan Politik (Al-Tamkin Al-Siyasi) Masyarakat Muslim Turki (Studi atas Kitab Al-Matsnawi An-Nuri)," An-Nida'38, no. 1 (2013): 60-68.

${ }^{4}$ Agus Riyadi, "Tarekat Sebagai Organisasi Tasawuf (Melacak Peran Tarekat dalam Perkembangan Dakwah)," Jurnal At-Taqaddum 6, no. 2 (2014): 359-85. serta upaya pengamalan ajarannya dengan berbagai cara seperti pola-pola, strategi, dan model-model tertentu. Usaha serta perjuangan tarekat tersebut juga tidak dapat dipisahkan dari peran aksi sosial, budaya, serta politik yang pada dasarnya diambil oleh tarekat sebagai suatu jalan keniscayaan yang empirik. Dengan begitu maka tarekat menjadi organisasi sosial yang sangat praktis yang bersentuhan dalam kehidupan sosial bermasyarakat. ${ }^{4}$

Studi terdahulu tentang tarekat umumnya mengangkat tema eksistensi dan mobilisasi tarekat itu sendiri. Di antaranya Syakur menekankan bahwa tarekat yang pada dasarnya hanyalah dimaksud sebagai metode, cara, serta jalan yang dilalui oleh seorang sufi dengan tujuan pencapaian spiritual tertinggi, terlebih dalam bentuk intensifikasi. ${ }^{5}$ Dalam konteks yang lebih luas, Khanafi menemukan bahwa kaum tarekat juga masih dianggap kurang berperan aktif dalam penyelesaian masalahmasalah kebangsaan yang semakin problematik. ${ }^{6}$ Namun stigma tersebut dibantah dalam studi Ahmadi dkk, seiring perkembangan waktu tarekat tidak hanya perperan sebagai spiritual tetapi juga sebagai gerakan perubahan sosial.

Secara umum studi tentang tarekat dan kolonial sedikit disinggung dalam studi

5 Abd. Syakur, "Mekanisme Pertahanan Diri Kaum Tarekat," Islamica: Jurnal Studi Keislaman 4, no. 2 (2014): 211, https://doi.org/10.15642/islamica.2010.4.2.211228.

6 Imam Khanafi, “Tarekat Kebangsaan: Kajian Antropologi Sufi Terhadap Pemikiran Nasionalisme Habib Luthfie," Jurnal Penelitian 10, no. 2 (2014): 337, https://doi.org/10.28918/jupe.v10i2.367.

7 Rizqa Ahmadi and Wildani Hefni, "Mobilitas Mursyid Cum-Aktivis dalam Tradisi Tarekat," Jurnal Theologia 30, no. 2 (2019): 220 , https://doi.org/10.21580/teo.2019.30.2.3647. 
Kaprabowo $^{8}$ Ravico9 dan Suherman ${ }^{10}$ bahwa bahwa pada masa penjajahan kolonial Belanda tarekat tersebut juga berperan dalam gerakan rakyat melawan penjajahan serta memeranginya. Sejumlah usaha serta gerakan dalam perlawanan besar yang dilakukan oleh beberapa tokoh tarekat serta pengikutnya di Nusantara. Dalam pandangan Azumardi Azra, sebagaimana dikutip oleh Jannah, respon pribumi Muslim mengenai penjajahan Belanda dikategorikan menjadi dua kelompok yaitu kelompok yang berusaha melakukan perlawanan secara terbuka atau terang-terangan serta kelompok yang melakukan perlawanan secara tertutup. ${ }^{11}$

Padahal dalam realitasnya, tarekat pun memang senantiasa dicurigai sebagai kekuatan yang mengancam karena berbagai tudingan dan tafsiran yang disematkan kepadanya karena perjuangan melawan ekonomi-politik. Tarekat memang memiliki modal sosial kuat sebagai alat pengorganisasi massa. Kepatuhan yang tidak mengenal kompromi dari para pengikutnya terhadap pemimpin spiritual dan cara hidup yang komunal adalah ciri tarekat. Belum lagi konteks sosial politik yang kemudian memancing para pemimpin spiritualnya untuk ikut serta dalam menyikapi ketidakadilan. ${ }^{12}$

Sifat tarekat yang sebenarnya serba devinisif dan serta diam akan tetapi jika dihadapkan dengan situasi dan kondisi yang tidak aman maka tarekat bias saja berubah menjadi aktif serta melawan dengan jibad asghar yaitu berjuang dengan fisik dapat berupa pemberontakan. Walaupun sebenarnya ajaran

8 Andi Kaprabowo, "Beyond Studies Tarekat Rifa'iyah Kalisalak: Doktrin, Jalan Dakwah, dan Perlawanan Sosial," Jurnal Pemberdayaan Masyarakat: Media Pemikiran dan Dakwah Pembangunan 3, no. 2 (2019): 378, https://doi.org/10.14421/jpm.2019.032-07.

${ }^{9}$ Ravico Ravico, "Hubungan Sosial-Politik Tarekat Samaniyah dengan Kesultanan Palembang Darussalam," Islamika: Jurnal Ilmu-Ilmu Keislaman 18, no. 2 (2019): 26, https://doi.org/10.32939/islamika.v18i02.308.

10 Suherman, "Perkembangan Tasawuf dan Kontribusinya di Indonesia," Jurnal Ilmiab Research Sains 5, no. 1 (2019): 21. yang utama mereka adalah tetap mengajarkan orang supaya tawakal dalam melakukan jihad akbar yaitu berusaha melawan hawa nafsu dalam diri sendiri. Tarekat yang pada dasarnya cenderung menekankan setiap ajaran dan amalannya tidak pernah berubah dan berlanjut terus. Namun dengan begitu tidak dapat kita pungkiri bahwa adanya perubahan dan menyesuaikan terhadap keadaan setempat serta keadaan sosial dan intelektual pada zamannya. Dengan demikian bisa terjadi perubahan dari tidak memerlukan dunia (zubud) menjadi melibatkan diri pada urusan dunia. ${ }^{13}$

Dalam penelitian terdahulu di atas umumnya membahas mengenai tarekat dan kultur perlawanan Islam Indonesia. Para peneliti tersebut masih mengelaborasikan peran tasawuf dan tarekat dalam kultur perlawanan seperti pemberontakan di Banten 1888 dan juga peran tasawuf secara umum di Nusantara. Namun masih minim mengelaborasi fokus pada peran satu tarekat lebih spesifik. Karena kultur tarekat bersifat komunal dibawah komando dan pengajaran spiritual tarekat. Dengan tidak mengecilkan peran tarekat lainnya dalam perlawanan terhadap kolonialisme, dinamika dan perlawanan Tarekat Qadiriyah wa Naqsyabandiyah menarik untuk dikaji lebih lanjut.

Penelusuran literatur tentang perlawanan Qadiriyah wa Naqsyabandiyah dapat dilakukan dengan penelitian kepustakaan dengan menelaah sumber primer dan sumber sekunder berupa buku, jurnal serta artikel-artikel lainnya yang terkait. Selanjutnya akan dilakukan analisis

11 Raudatun Jannah, "Peran Tarekat Sammaniyah dalam Perang Menteng Melawan Kolonial Belanda di Palembang," Medina-Te: Jurnal Studi Islam, 2017, https://doi.org/10.19109/medinate.v13i2.3483.

12 Muhammad Azka Fahriza, "Tarekat dan Kultur Perlawanan Islam Indonesia," Siasat Journal of Social, Cultur and Political Studies 3, no. 2 (2019): 46, https://doi.org/10.33258/siasat.v1i2.10.

13 L. Hidayat Siregar, "Sejarah, Pemikiran dan Gerakan Politik Tarekat (Mencermati Politik Tarekat Naqsyabandiyah di Indonesia)," Sosio-Religia 8, no. 2 (2009): 140-53. 
data dengan menggunakan kontens analisis berupa menganalisis isi literatur untuk menjawab fokus penelitian.

Dengan demikian, studi ini fokus menjelaskan tentang peran Tarekat Qadiriyah wa Naqsyabandiyah pada tahun 1888-1903. Periode tersebut merupakan fase dimana tarekat ini berperan dalam perlawanan terhadap penjajahan kolonialisme di Indonesia. Dinamika dan pergolakan tarekat penting dikaji lebih spesifik karena stigma tentang tarekat yang bersifat ekslusif, asketik terbantahkan dalam penelitian ini.

\section{Perubahan Orientasi dalam Tasawuf dan Tarekat: Aktifisme dan Radikalisme}

Dengan munculnya ajaran-ajaran tasawuf sama dengan munculnya Islam itu sendiri sebagai agama yang masuk di Indonesia tersebut. Sebagai mubaligh yang mneyebarluaskan Islam di Indonesia ini telah mengenalkan ajaran Islam dalam bentuk kapasitas mereka sebagai seorang guru sufi. Tradisi serta corak tasawuf telah menanamkan benih yang fundamental dalam pembentukan sikpa dan mentalitas bagi kehidupan sosial masyarakat Islam di Indonesia sendiri. ${ }^{14}$

Doktrin neo-sufisme yang mengejewantah dalam kehidupan pribadi para sufimse penduduknya menunjukkan bahwa tasawuf yang sudah diperbaharui sama sekali tidak mentolerir sikap cara yang hanya menerima saja serta penarikan diri (u₹lab) dari hingar bingarnya kehidupan ini. Sebaliknya mereka justru menganjurkan para pengikutnya aktif memenuhi kewajiban duniawi tanpa mengorbankan pemenuhan disipilin spiritual. ${ }^{15}$

Salah satu alasan mengapa tasawuf sering digambarkan sebagai non-kekerasan adalah tasawuf penekanan historis pada asketisme. Banyak sufi awal mempertanyakan apakah seseorang dapat secara bersama fokus pada hubungan langsung dan langsung dengan Tuhan, dan masih terlibat dalam dunia material. Dengan demikian banyak pertapa sufi awal mengabdikan seluruh hidup mereka sematamata untuk Tuhan, sementara menghapusnya diri dari urusan masyarakat mereka. Tetapi ada juga banyak contoh dalam sejarah di mana para sufi, apakah syeikh sufi atau penganut sufi akan mengabdikan hidup mereka untuk mencapai Tuhan di bumi, tetapi melakukannya sementara masih sangat banyak terlibat dalam komunitas masing-masing. Sufi tidak hanya memperdebatkan peran asketisme, materialisme, dan Syariah tetapi banyak juga sufi yang terlibat dalam kampanye politik (dan militer anti-kolonial) sebagai cara untuk tidak hanya lebih dekat dengan Tuhan, tetapi juga untuk menekankan pentingnya konsep keadilan dalam Islam. ${ }^{16}$

Komunitas sufi biasanya digambarkan sebagai kekuatan pendiam dan non-politik atau sebagai instrumen sederhana dominasi Negara. Namun, peran penting yang diperintahkan oleh sufi dalam banyak pemberontakan terhadap Negara, kekuatan kolonial, dan Negara-negara otoriter tengah bertentangan dengan sudut tersebut. Baik kolaborasi dan penolakan terhadap Negara hadir sebagai starategi politik di antara komuntias sufi di masa kini. Kolaborasi tersebut dapat dicontohkan dalam "Islam resmi" yang diberitakan oleh Naqsyabandiyya Kuftariyya, dan perlawanan oleh keterlibatan cabang Shahdiliyya dalam perjuangan bersenjata yang dilancarkan oposisi

16 Fait Muedini, "Sufism and Anti-Colonial Violent Resistance Movements: The Qadiriyya and Sanussi Orders in Algeria and Libya," Open Theology 12, no. 1 (2015): 136, https://doi.org/10.1515/opth-20150003 .
Tarekat Qadiriyah wa Naqsabandiyah di Jawa Timur, Pada Masa Kepemimpinan Mursyid KH Mustain Romly 1958-1984," Journal Pendidikan Sejarab 5, no. 3 (2017): 910.

15 HS Mastuki, "Neo-Sufisme di Nusantara Kesinambungan dan Perubahan," Jurnal Kebudayaan dan Peradaban Ulumul Qur'an 6, no. 1 (1997): 51-61. 
Islam melawan Rezim Ba dari 1979 hingga 1982. ${ }^{17}$

Oleh karena itu maka tasawuf menyediakan berbagai bentuk artikulasi, sufisme tidak berkembang secara sepihak sebagai reaksi atas perubahan tetapi juga melengkapi dan juga berpatisipasi dalam perubahan tersebut. ${ }^{18}$

Gejala kebangkitan spiritualitas (aspek keruhanian) menurut Harun Nasution mengatakan bahwa pada akhir abad ini orangorang justru kembali dan mencari keruhanian kembali. Serta ada yang kembali kepada agamanya semula walaupun tidak dengan keyakinan penuh. Dengan ungkapan seperti: "pada dasarnya saya kurang percaya dengan agama saya sendiri, namun melihat kericuhan serta porak-poranda nilai-nilai yang berkembang dengan kemjuan iptek pada saat ini justru saya haru mempunyai pegangan tersendiri. Jikalau tidak kehidupan saya juga akan mengalami kekacauan seperti yang saya sebutkan tadi. Kemudian ada juga yang berpindah ke agama yang lain terutama agama yang ada pada dunia Timur. Karena agama yang berada di Barat juga banyak dipengaruhi oleh beberapa kematerian yang melanda masyarakat tersebut. Kemudian ada juga yang ke gerakan keruhanian pada luar agama, serta ada juga yang lari mencari keruhanian pada psiklogi. Menurutnya hidup hanya sebatas kematerian justru tidak akan memuaskan tanpa berpegang kepada agama, dengan begitu selain hidup dengan kematerian juga diperlukan keruhanian, literatur agama serta keruhanian mulai digali kembali".

William McInner juga mengatakan berupa hal yang juga sama bahwa dengan perkembangan baru dalam agama pada apad ke21 ini selanjutnya bias ditandai dengan

17 Paulo Pinto, "Dangerous Liaisons: Sufism and the State in Syria," JIWM Junior Visiting Fellows' Conferences 14, no. 1 (2003): 2.

18 Jamal Malik and Hinnells Jhon, Sufism in the West (New York: New York University Press, 2017), 23. perkembangan spiritual yang sangat mendalam. Dalam hal tersebut munculnya persepsi bahawa dalam ajaran tasawuf ketenangan hidup serta kebahagiaan dalam dunia modern ini dapat kita jumpai atau paling tidak dicari adalah sesuatu yang tidak berlebih-lebihan. ${ }^{19}$

Dalam menjalankan kehidupan pada saat ini, dengan situasi masyarakat yang lebih mengarah kepada keboboran moral, dominasi pragmatisme, hilangnya rasa kepercayaan diri, melemahnya rasa persatuan dan kesatuan, rasa persaudaraan, rasa kasih sayang serta rasa toleransi. Maka dari itu sufi mulai mendapat pandangan utama serta di tuntut peran aktifnya dalam upaya mengatasi masalah-masalah yang sedang dihadapi masyarakat. Dalam hal tersebut menarik untuk mengadakan pencarian mengenai muncul serta perkembangan tasawuf dalam kajian pemikiran Islam Klasik. Di mana tasawuf datang disaat umat Islam berada dalam puncak kejayaannya. Rasionalisme dalam filsafat serta formalisme dalam kajian fikih sangat berkembang dengan pesatnya di kalangan umat pada masa dinasty 'Abbasiyyah. Tanpa kita sadari bahwa justru menjadikan umat pada sikap yang cenderung kepada rasionalistik serta materialistik dan bahkan memarginalitaskan aspek ruhani tersebut. Situasi seperti itu membuat kering dan dangkalnya ruhani seseorang. Dengan bergelimangan harta serta kemewahan dan kekayaan justru dapat menjerumuskan kita kepada kehidupan yang berfoya-foya, berbuat dosa, menzalimi, serta intoleran yang pada akhirnya melupakan bahwa tugasnya sebagai Khalifah di dunia ini (khalifat fi al-ard), mestinya mengikuti perintah dan larangan Allah.

Maka dari itu justru sufi muncul dengan cara yang lain untuk menyelamatkan Islam dari proses rasionalisasi serta kehidupan yang

19 Syamsun Ni'am, “Tasawuf di Tengah Perubahan Sosial (Studi Tentang Peran Tarekat dalam Dinamika Sosial-Politik di Indonesia)," Harmoni 15, no. 2 (2016): 123-37. 
materialistik yang membuat umat jauh dari keruhanian serta membuat keimanan dangkal serta mengeringnya ketakawaannya. Walaupun sbagian orang mengatakan bahwa tasawuflah yang menjadi biang kerok serta membuat kemunduran umat Islam. Namun anggapan seperti itulah yang telah salah faham, sebab ketika kita meninggalkan tasawuf serta ajaran spiritualnya maka dari itu berarti secara tidak langsung kita telah meninggalkan sumbersumber keruhanian agama itu sendiri.

Pandangan yang utama bagi kalangan sufi adalah suatu perjalanan jiwa yang dapat membimbing serta mengajarkan perilaku baik dan meninggalkan perbuatan jahat, serta mengendalikan diri untuk selalu tunduk dan melawan hawa nafsu. Disebutkan bahwa keadaan umat yang condong kepada kemerosotan nilai-nilai moral di tengah-tengah dinamika sosial-politik global seperti saat ini. Semua itu akibat dari nilai-nilai keruhanian yang semakin merosot, sehingga secara tidak sadar kehilangan pegangan. Lebih lagi dengan berkembangnya arus modernisai disegala hal yang menghasilkan suatu proses liberalisai serta rasionalisasi, secara konsisten terus melakukan pendangakan kepada spiritualitas. ${ }^{20}$

Upaya sufi untuk mengatasi perubahan modern dan terlibat dalam pekerjaan sosial umum terjadi sementara secara bersamaan mempersiapkan dan memobilisasi para pemimpin untuk garis depan perjuangan politik menyebabkan perintah sufi untuk memperoleh peran katalis aktif, sebagai lawan dari reaksioner kekuatan, dengan demikian menarik banyak tokoh politik. Pola ini menemukan kepercayaan dalam sejarah bukti, seperti Abdullah ibn AlMubarak, Syekh Shamil di Dagestan, al-Amir

${ }^{20}$ Ni'am, "Tasawuf di Tengah Perubahan Sosial (Studi Tentang Peran Tarekat dalam Dinamika SosialPolitik di Indonesia)," 124.

${ }^{21}$ Tarek Ladjal and Benaouda Bensaid, "Sufism and Politics in Contemporary Egypt: A Study of Sufi Political Engagement in the Pre and Post-Revolutionary Reality of January 2011," Journal of Asian and African
Abdul Qadir master dari tarekat sufi Qadariyyah di Aljazair, Umar al-Mukhtar pemimpin di Libya, sejarah modern juga penuh dengan contoh serupa dalam kasus Gerakan Nur, tatanan Naqsyabandi di Turki, kebangkitan Najm al-Din Arbakan dan Partai Keadilan dan Pembangunan di Turki. Yang juga penting adalah kontribusi yang dibuat oleh pesanan sufi Muriddiyah dan Tijaniyyah di Afrika Barat, terutama di Senegal. ${ }^{21}$

Oleh karena itu banyak mode interaksi yang saling menguntungkan antara sufi dan tokoh-tokoh poltik seperti seorang sufi sebagai penunjuk, dimana orang sufi menggunakan wawasan ilahi yang diberikan dan meramalkan kesuksesan besar untuk tokoh-tokoh jauh sebelum mereka memiliki mencapai ketenaran. $^{22}$

Peran penting sufisme tak dapat dipisahkan dari usaha dan kiprah para ulama sufi yang merupakan pengamalan ajaran tasawuf. Jauh sebelum Indonesia lahir, ajaran ajaran tasawuf dipopulerkan oleh Hamzah Fanzuri, Syamsuddin al-Sumaterani, al-Raniri, al-Sinkili, dan al-Makassari. Hamzah Fanzuri berasal dari Pantai Barat Sumatera beliau adalah pertama kali yang memperkenalkan tarekat di Indonesia serta beliau juga seorang ulama sufi. Dia tercatat pernah mengunjungi: Makkah, Madinah, Yerusalem serta Baghdad bertujuan untuk memperdalam ilmu keislaman. ${ }^{23}$

Dalam hal tersebut sikap aktivisme jelas tampak pada mereka menampilkan diri mereka sebagai sufi-sufi teladan. Dan tidak hanya berasyik maksyuk dengan pengembara spiritualnya di jalan Allah. Tetapi juga memenuhi tugas-tugas duniawinya. Keterlibatan mereka dalam bidang politik dan

Studies 50, no. 4 (2015): 471, https://doi.org/10.1177/0021909614534170.

22 Omid Safi, "Bargaining with Baraka: Persian Sufism, 'Mysticism,' and Pre-Modern Politics," Muslim World 18, no. 1 (2007): 266, https://doi.org/10.1111/j.1478-1913.2000.tb03691.x.

23 Ahmad Amir Azis, Teologi Kaum Tarekat (Yogyakarta: Trussmedia Grafiti, 2020), 58. 
pemerintahan dengan menjadi mufti atau Syaikh al-Islam menjadi contoh sifat aktifis mereka. Al-Makassari bahkan berjalan lebih jauh dan menjadi seorang pahlawan serta pemimpin terepenting dalam aksi perang Banten Melawan kolonial Belanda. Hal yang sama terjadi pada para ulama abad ke-18. Arsyad al-Banjari adalah perintis diadakannya jabatan mufti dan didirikannya lembaga pendidikan Islam dikesultanan Banjar. ${ }^{24}$

Anjuran jihad serta ciri lain dari aktivisme juga datang dari al-Palimbani dan al-Fatani. AlPalimbani diketahui mensuport kawan-kawan sebangsa Melayu Nusantara dengan tujuan berjihad dan melancarkan usahanya melawan kolonialsime Belanda lebih dari satu kali, sampai-sampai oleh Drewes dia disebutnya memiliki keahlian khusus di bidang ini, selain soal-soal agama. karya utama al-Palimbani tentang jihad, Fadblail al-Jihad, ditulis dalam bahasa Arab yang mungkin dimaksudkan agar tidak diketahui maksudnya oleh Belanda ${ }^{25}$. Snouck Hourgronje menyatakan bahwa kitab ini menjadi sumber pertama dari berbagai karya dalam usaha berjihad dalam perang Aceh. Ia menjadi versi dan model Aceh mengenai himbaun pada masyarakat muslimin supaya melawan serta berjuang melawan kaum kafir. Anjuran jihad ini juga dilakukan melalui suratsurat yang dikirimkan misalnya kepada penguasa Jawa, Sultan Mataram, Hamengkubuwono I tertanggal 22 Mei 1772. Terhadap surat-surat al-Palimbani ini, Ricklefs menyipulkan adanya bukti histois dalam perjuangan kaum Muslimin Melayu Nusantara melawan Belanda. ${ }^{26}$

\footnotetext{
24 Mastuki, "Neo-Sufisme di Nusantara Kesinambungan dan Perubahan," 53

${ }^{25}$ Al-Palimbani, Fadhlail al-Jihad, dalam MMS No CCIX dan V.d.W; Leiden University, F.Or. A 20c

26 Mastuki, "Neo-Sufisme di Nusantara Kesinambungan dan Perubahan," 54.

27 Mahrus As'ad, "Pengaruh Neosufisme terhadap Perkembangan Tasawuf dan Tarekat Baru,"
}

Dengan begitu kepentingan serta aktifitas tarekat sangat mudah sekali berubah serta menjadi gerakan jihad yang bertujuan melawan serta menjadi kekuatan-kekuatan yang dianggap sebagai musuh Islam. Al-Palimbani dalam memaknai jihad cenderung secara fisik dan jelas menjadi suatu persoalan yang sendiri serta mengingat, pertama potensi-potensi makna dalam jihad tersebut sangat luas serta tidak dibatasi dalam aspek perjuangan fisik ${ }^{27}$. Namun jihad tersebut juga juga mencakup perjuangan secara intelektual serta spiritual. Kedua ketokohan al-Palimbani tersebut di dalam dunia intelektual serta spiritual yang tidak perlu disangsikan lagi. ${ }^{28}$

Kesetiaannya pada Islam di Indonesia pada gilirannya memperkuat atas kesadaran keejarahan serta pengalaman yang sama. Dalam artian tersebut colonial Belanda yang pada dasarnya secara teologis dalam pandangan ajaran Islam adalah kafir yag merupakan semacam blessing in disguise. Dengan kata lain penjajahan dari Belanda mendorong berbagai kelompok etnis di Indonesia yang bersatu pada tingkatan teologis keagamaan. ${ }^{29}$

Dengan adanya anjuran jihad dari para sufi ini, tidak aneh lagi kalau Snouck kemudian menyatakan bahwa guru-guru sufi merupakan musuh paling berbahaya bagi kelanjutan kolonialisme di Nusantara. Dalam banyak hal aktifisme yang muncul dikalangan tasawuf (sufi) tampaknya tidak begitu berbeda dengan yang terjadi dikalangan tarekat. Meskipun tidak selalu signifikan mengaitkan aktivisme yang terjadi dalam tasawuf mempengaruhi aktivisme (dan radikalisme) dalam tarekat, namun, setidaknya akar-akarnya dapat ditelusuri dari sini. ${ }^{30}$

Miqot: Jurnal Ilmu-Ilmu Keislaman 7, no 3 (2016): 23, https://doi.org/10.30821/miqot.v36i1.107.

28 Asep Saefullah and Agus Permana, "AlPalimbani dan Konsep Jihad," Al-Tsaqafa: Jurnal Ilmiah Peradaban Islam 16, no. 2 (2019): 176-87.

29 Saefullah and Permana, "Al-Palimbani dan Konsep Jihad," 34 .

30 Mastuki, "Neo-Sufisme di Nusantara Kesinambungan dan Perubahan," 54 
Perubahan baru terjadi akhir-akhir abad ke-18 dan awal-awal abad ke-19. Dalam kurun waktu tersebut ada ada fenomena yang sangat menarik nahwa tarekat sudah mulai menjadi sebuah perhimpunan sosial bahkan tarekat membentuk jaringan yang lebih meluas. Isyaratisyarat datangnya "Radikalisme" dalam tubuh tarekat mulai menampakan diri. barangkali tarekat yang pertama kali yang memperoleh banyak pengikut di Asia Tenggara yang benarbenar dapat dimobilisasi adalah tarekat Samaniyyah. Meskipun sangat dipeningkan oleh Sultan Palembang (kalangan istana), tarekat ini jusru mendapatkan pengikut yang sangat banyak dikalangan masyarakat awam. ${ }^{31}$

Perlawanan besar juga muncul di Sumatera Barat tahun 1908 ternyata didalangi tarekat Syatariyyah yang sudah lama berpengaruh di wilayah ini. Dalam rentang waktu abad ke-19 dan abad ke-20 adalah melibatkan perlawanan para tarekat. Sebagaian besar diantaranya merupakan gerakan menentang kolonialisme Belanda yang semakin mengokohkan dirinya di seluruh kepulauan Nusantara. Motivasi lain dari pemberontakan ini merupakan respon terhadap peraturan-peraturan tertentu yang diterapkan pemerintah serta respon pada kemerosotan kehidupan sosio-ekonomi masyarakat serta penindasan. ${ }^{32}$

\section{Sejarah Tarekat Qadiriyah Naqsyabandiyah}

Tarekat Qadiriyah wa Naqsyabandiyah adalah sebuah tarekat gabungan dari tarekat Qadiriyah dan tarekat Naqsyabandiyah. Tarekat Qadiriyah wa Naqsyabandiyah tersebut tersebar luas dan paling aktif di Indonesia. ${ }^{33}$ Tarekat tersebut pertama kali diluncurkan oleh Syaikh Ahmad Khatib Sambas yang terkenal sebagai seorang penulis Kitab Fath al-Arifin. Nama Sambas tersebut adalah sebuah kota di sebelah Utara Pontianak, Kalimantan Barat. Syaikh Naquib al-Attas mengatakan bahwa tarekat Qadiriyah wa Naqsyabandiyah adalahs ebuah tarekat gabungan karena Syaikh Sambas mengajarkan tarekat dalam satu versi. Dalam zikirnya mengajarkan zikir dalam hati dalam tarekat Naqsyabandiyah, sedangkan zikir secara keras dalam tarekat Qadiriyah maka dari itu disebutlah dengan tarekat Qasiriyah wa Naqsyabandiyah. ${ }^{34}$

Tarekat Qadiriyah wa Naqsyabandiyah yang terdapat di Indonesia sendiri bukanlah hanya suatu asal-asalan penggabungan dari dua tarekat yang berbeda yang diamalkan bersamasama saja. Akan tetapi tarekat ini lebih memodifikasi yang baru serta berdiri sendiri, yang di dalamnya terdapat unsur-unsur pilihan dari Qadiriyah dan juga Naqsyabandiyah yang telah dipadukan menjadi sesuatu yang baru. ${ }^{35}$

Setelah belajar pendidikan agama dasar di kampong halamannya, Syaikh Sambas tersebut langsung pergi ke Makkah, pada saat itu usianya beranjak sembilas tahun untuk meneruskan studinya serta menetap di Makkah sehingga beliau wafat di sana pada tahun $1289 \mathrm{H} / 1872$. Di Makkah itu sendiri beliau banyak belajar berupa ilmu-ilmu keislaman berupa tasawuf serta beliau mendapatkan posisi yang lebih tinggi dibandingkan teman-teman seperjuangannya. Tidak hanya itu beliau juga menjadi seorang tokoh yang sangat berperan penting dan sangat berpengaruh besar di Indonesia. Di antara gurunya adalah Syaikh Daud bin Abd Allah bin Idris al-Fatani seorang alim besar yang juga tinggal di Makkah, yaitu Syaikh Syams al-Din, Syaikh Muhammad

\footnotetext{
31 Mastuki, "Neo-Sufisme di Nusantara Kesinambungan dan Perubahan," 55.

32 Mastuki, "Neo-Sufisme di Nusantara Kesinambungan dan Perubahan," 55.

${ }^{33}$ Abdurrahman, Tarekat Qadiriyah Naqsyabandiyah Studi Etnografi Tarekat Sufi di Indonesia (Yogyakarta: Deepublish, 2015), 2.
}

34 Sri Mulyati, Tarekat-Tarekat Muktabarah di Indonesia (Jakarta: Kencana Prenada Media Group, 2011), 58.

${ }^{35}$ Martin Van Bruinessen, Tarekat Naqsyabandiyah di Indonesia (Bandung: Mizan, 1992), 43. 
Arsyad al-Banjari. Dari semua murid-murid Syaikh Syams al-Din, Ahmad Khatib Sambaslah yang dapat mencapai tingkatan yang tertinggi dan kemudian dinobatkan sebagai Syaikh Murshid Kamil Mukammil. ${ }^{36}$

\section{Peran Tarekat Qadiriyah wa Naqsyabandiyah dalam Melawan Kolonial Belanda}

\section{Peran dan Aksi-aksi Sosial Tarekat}

Sebagai suatu tatanan sosial, tarekat tidak bisa menghindari dari masalah sosial politik. Dengan begitu maka penguatan kekuatan tarekat sangat berpotensi untuk menjadi suatu wadah penampung aspirasi para murid-murid serta masyarakat yang berusaha melawan ketertindasan serta ketidakadilan, penguasa despotic serta berbagai macam bentuk penindasan terhadap masyarakat. Tarekatpun juga mengajarkan kehidupan yang harmonis, kesejahteraan serta kebahagiaan lahir dan bathin. Oleh karena itu maka tarekatpun tidak bisa menutup mata dan tidak mau merespon serta berdiam diri dengan kejadian seperti hal tersebut. Yang berpotensi sosial yang kuat serta diikat dengan rasa kebersamaan dan ketaatan dengan tujuan searah kepada pemimpin spiritual. Maka dari itu institusi tarekat sangat berpotensi menjadi sebuah gerakan atau perlawanan terhadap kolonial Belanda. Ada pula suatu kasus pada tarekat yang secara formal berkeinginan serta bergerak untuk mendirikan sebuah system pemerintahan sendiri dengan tujuan menguatkan eksistensinya serta untuk memperlancar perkembangannya. ${ }^{37}$

Dalam sejarah telah dicatat bahwa kisaran abad ke-18, 19, serta 20 tarekat sebagai institusi sosio-reloigius yang telah menunjukkan fungsi politiknya tersebut. Tarekat menjadi sebuah wadah serta menampung aspirasi masyarakat yang kemudian menjadi sebuah gerakan perlawanan atas ketidakadilan yang dilakukan oleh kolonial Belanda. Kasus yang terjadi di daerah Nusantara termasuk daerah Jawa seperti: Gerakan Petani Banten pada tahun 1888. Gerakan tersebut bermula dengan pembebanan pajak yang sangat berat dari pemerintahan Belanda. Kemudian semakin menguatnya karena ada suntikan senitimen keagamaan di bawah pimpinan tarekat Qadiriyah wa Naqsyabandiyah yang pada dasarnya mampu membuat semangat rakyat serta gejolak semangat rakyat untuk melawan penjajahan tersebut. Kasus tersebut bertepatan terjadi pada tanggal 9 Juli 1888. Kemudian Gerakan tarekat Qadiriyah wa Naqsyabandiyah di daerah Blitar, kemudian pemberontakan kaum tarekat Qadiriyah wa Naqsyabandiyah di daerah Bogor, Garut, Cianjur, Cirebon, serta Sidoarjo yang pada dasarnya bertemakan melawan kolonial Belanda. ${ }^{38}$

Semua gerakan perlawanan tersebuut sangat jelas terlihat bahwa tarekat juga bisa berkontribusi dalam masalah sosial politik masyarakat dan mewujudkan kehidupan yang sangat didambakan. Maka dari itu dapat kita lihat bahwa tarekat yang pada awalnya hanyalah merupakan asosiasi spiritual yag bersahaja serta berevolusi secara organic baik dari struktur maupun secara fungsional sehingga menjadikan suatu organisasi yang dinamik serta fleksibel dalam kehidupan yang praktis serta dengan peran-perannya yang sangat bervariasi. ${ }^{39}$

Ide dan usaha penyatuan kedua tarekat ini adalah langkah politik besar dalam merancang, mengurus, mengendalikan, menjaga kemaslahatan serta menjauhkan dari keburukan. Dan ini merupakan hakekat inti dan

\footnotetext{
38 Syakur, "Mekanisme Pertahanan Diri Kaum Tarekat," 215.

39 Syakur, "Mekanisme Pertahanan Diri Kaum Tarekat," 216
} 
tujuan utama aktifitas politik dalam syariah Islam. $^{40}$

Dalam menyatukan kedua tarekat ini juga tidak dapat dipisahkan dari realitas sosial politik umat Islam yang sedang menghadapi persoalan yang sangat besar baik dari eksternal maupun dari internal. Faktor eksternal tersebut muncul dari kolonialisme penjajahan yang menguasai hamper pada seluruh dunia Islam yang juga termasuk di daerah Nusantara. Dalam kasus tersebut tidak hanya yang bersifat politik serta kekuasaan akan tetapi di situ terkandung miss kristeniasi serta program sekularisasi yang menjadikan umat Islam dalam sebuah organisasi yang sempit. Pertama, Islam dibatasi hanya dalam bidang agama yang murni (ibadah), kedua, pada tatanan dalam bidang sosial kemasyrakatan pemerintah kolonialisme memanfaatkan hukum adat sebagai sebuah aturan dalam perundangan. Ketiga, dalam bidang politik pemerintahan kolonial Belanda mencegah setiap usaha yang akan membawa rakyat kepada faham fanatisme politik panIslam. $^{41}$

Ketika Syaikh Ahmad Khatib Sambas wafat, kedudukannya digantikan oleh khalifahnya, syaikh Abdul Karim Banten. Abdul Karim menunaikan tugas itu sejak tahun 1967, dan tetap berdomisili di Makkah. Tidak hanya Abdul Karim, Syaikh Khatib juga telah memberikan ijazah kepada beberapa khalifah penting lainnya, yaitu Syaikh Tolha Cirebon, dan Syaikh Ahmad Hasbullah asal Madura namun, menetap di Makkah. ${ }^{42}$

\section{Kontribusi dalam Perjuangan di Indonesia}

Seketika tasawuf berubah dan melembaga menjadi suatu organisasi tarekat, akhirnya pertambahan jumlah penganut tarekat

${ }^{40}$ Didik M Nur Haris and Rahimin Affandi Abdul Rahim, "Akar Tradisi Politik Sufi Ulama Kalimantan Barat Abad Ke-19 dan 20," Ijtimaiyya: Jurnal Pengembangan Masyarakat Islam 10, no. 1 (2018): 47, https://doi.org/10.24042/ijpmi.v10i1.2355.

41 Haris and Rahim, "Akar Tradisi Politik Sufi Ulama Kalimantan Barat Abad Ke-19 dan 20," 48. berkembang sangat cepat, walaupun mayoritas penganut tarekat tersebut adalah penganut awam. Namun dalam pandangan tarekat adalah sebagai sebuah organisasi maka pertambahahan penganut tarekat tersebut adalah merupakan hal yang sangat posistif dalam artian semakin bertambahnya penganut tarekat maka semakin membesarnya organisasi tersebut. Walaupun suatu lembaga serta metode tarekatpun sudah mulai menyebar sejak abad ke-16, namun tarekat dikatakan sebagai organisasi baru mulai kelihatan akhir abad ke-18 kemudian menjadi suatu fenomena pada abad berikutnya. Dengan menjadikan tarekat suatu organisasi maka dari itu lebih memiliki jaringan yang sangat luas, sesuai dengan tingkat penyebarnnya. Tarekat suatu organisai juga mengembangkan kecendrungan mengirim perwakilan-perwakilan atau kahlifah, serta badal ke daerah-daerah tertentu. ${ }^{43}$

Tarekat melembaga dalam organisasi seperti itulah yang sangat berperan aktif dalam berbagai pristiwa terkhusus dalam protesprotes menentang kolonial Belanda. Kita dapat melihat peranannya dalam maelawan penjajahan oleh para pengikut tarekat Qadiriyah wa Naqsybandiyah. Dalam pemberontakan Banten (1888) yang sangat terkenal terdapat indikasi kuat keterlibatan tarekat Qadiriyah wa Naqsyabandiyah, khsususnya dalam menyediakan suatu jaringan mobilisasi masa. Tarekat yang sama juga berperan dalam pertentangan Muslim-Hindu di Lombok pada tahun 1891. Ketika Belanda memberlakukan pajak baru atas komoditi tembakau di Sumatera Barat, masyarakat juga ikut bangkit melawan penjajahan tersebut. ${ }^{44}$

\footnotetext{
42 Azis, Teologi Kaum Tarekat, 58 .

43 Suherman, "Perkembangan Tasawuf dan Kontribusinya di Indonesia,” 21

44 Suherman, "Perkembangan Tasawuf dan Kontribusinya di Indonesia,” 23.
} 
Pada tradisi tarekat mereka menunjukkan lagi sikap inklusif yang secara umum, dimiliki oleh ulama yang berada di lingkungan "jaringan Haramain". Fenomena lain juga bisa di amati bahwa para penyebar tarekat-tarekat ini mungkin dalam mengajarkan kepada penganutpenganutnya tidak banyak melebihi dari bacaan-bacaan berzikir serta wirid yang diamalkan secara pribadi, dan merupakan bagian yang tak terpisahkan dari praktek dan ajaran sufi. ${ }^{45}$

Sebuah karya sastra daerah bertempat bertajuk Syair Perang Menteng (dalam perang disebut dengan nama komandan pasukan Belanda, Muntinghe, yang dalam bahasa Melayu disebut Menteng). Dalam perang Mentang tersebut menceritakan bagaimana peran serta aksi tarekat dalam memainkan perannya dalam melawan hegemoni Belanda pada tahun $1819^{46}$. Sebagian kelompok orang-orang yang berpakaian serba putih (dalam syair disebut haji) berzikir keras membaca asma Allah (alMalik, al-Jabbar) sampai mencapai eksrase (fana) serta tanpa adanya rasa gentar dan takut saat menyerang musuh. Dan mereka yakin bahwa tubuh mereka kebal dari kekuatan zikir tersebut dan berjihad melawan kolonial Belanda. ${ }^{47}$

Beberapa kasus lain di mana tarekat mengambil peranan dalam pemberontakkan antikolonial dapat ditemukan didaerah-daerah lain selama akhir abad ke-19 dan awal abad ke20. Salah satu pemberontakkan yang paling besar serta cukup merepotkan petani Banten. Di sini tarekat Qadiriyyah wa Naqsyabandiyah disebut juga terlibat. Walaupun mungkin secara tidak langsung. ${ }^{48}$

Tarekat ini dilekatkan kepada seorang ulama asal Kalimantan yang menetap di Makkah pada pertengahan abad ke-19 bernama

45 Mastuki, "Neo-Sufisme di Nusantara Kesinambungan dan Perubahan," 57

46"Syair Perang Menteng" ditemukan di situs khastara.perpusnas.go.id dengan catalog ID 220226

47 Mastuki, "Neo-Sufisme di Nusantara Kesinambungan dan Perubahan," 58
Ahmad Khatib Sambas. Beliaulah yang menggabungkan tradisi tarekat Qadiriyyah dan Naqsyabandiyah sehingga menjadi khas, dan menjadi tarekat baru dengan nama Qadiriyyah wa Naqsyabandiyah. Setelah Ahmad Khatib wafat diagantikan oleh kahlifahnya, Syaikh Abdul Karim Banten (yang juga menetap di Makkah), kemampuan Syaikh Abdul Karim ini menyebabkan tarekat ini berkembang begitu pesatnya, terutama pada daerah Banten serta daerah-daerah lainnya seperti Sumatera Selatan sampai ke Lombok. Tidak hanya Abdul Karim, Syaikh Ahmad Khatib juga memberikan ijazah kepada dua khalifah penting lainnya, yaitu Syaikh Tholhah dari daerah Cirebon dan Kiai Ahmad Hasbullah bin Muhammad dari daerah Madura. Walaupun pengaruh mereka lebih bersifat lokal, namun juga melahirkan cabang tarekat yang cukup luas pengaruhnya. ${ }^{49}$

Ajid Tohir menguraikan peran penting Tarekat Qadiriyah wa Naqsyabandiyah dalam gerakan anti-kolonialisme di Jawa. Dia menyebut adanya perubahan orientasi gerakan tarekat dari gerakan keagamaan murni ke gerakan religio-politik. Pada tahap awal tarekat Qadiriyah wa Naqsyabandiyah di Jawa lebih banyak berfungsi sebagai wadah kegiatan spiritual dan sarana mencapai kesempurnaan keruhanian yang bertingkat, pada perkembanganya terutama pada tahun 18881904 ketika situasi sosial berubah, terjadi pula pergeseran tarekat sebagai sistem religiopolitik $^{50}$. Para pemipmin tarekat tersadarkan oleh kondisi terjajahnya masyarakat. Struktur pendukung sebagai determinan sejarah gerakan juga cukup konkrit, yaitu keresahan sosial akibat tekanan ekonomi dan kemerosotan standar kehidupan rakyat jajahannya yang memunculkan paham mileniarisme dan
48 Mastuki, "Neo-Sufisme di Nusantara Kesinambungan dan Perubahan," 61.

49 Mastuki, "Neo-Sufisme di Nusantara Kesinambungan dan Perubahan," 3.

50 "Syair Perang Menteng" 
mahdisisme. Hal ini ditandai dengan gerakan pemberontakan petani di Banten pada tahun 1888.51

Juli pada tahun 1888, wilayah Anyer Banten mengalami pemberontakan yaitu pemberontakan Petani. Yang sering kali disertai harapan yang mesianistik. Memang sudah terjadi di Jawa sebelumnya, terutama pada abad ke-19, kemudian Banten adalah salah satu daerah yang sering mengalami berontakan. Namun demikian, pemberontakan yang satu ini lebih menguncang Belanda. Namun penumpasannya tidak begitu merepotkan Belanda. Akan tetapi pemberontakan pada saat itu sangat memprihatinkan. Dalam pemberontakan tersebut banyak diikuti oleh pemimpin para kiay serta haji-haji. ${ }^{52}$ Perlawanan rakyat Banten tersebut adalah kelanjutan dari abad-abad sebelumnya di mana tarekat dan masyarakat yang mempertahankan diri dari kolonial Belanda. ${ }^{53}$

Dalam pimpinan Abd Karim, tarekat inipun menjadi luar biasa populernya di daerah Banten, terkhusus diantara penduduk miskin di desa-desa. Tarekat ini sangat berperan sebagai suatu jaringan komunikasi serta koordinasi seketika apa yang dikatakan sebagai suatu pemberiontakan petani paling besar kemudian meletus di Banten Barat pada tahun 1888. ${ }^{54}$

Penyelidikan menunjukkan bahwa banyak kiay dan haji yang ikut berperan dalam aksi pemberontakan tersebut, namun para kiay dan haji tersebut adalah pengikut tarekat Qadiriyah wa Nasyabandiyah. yang dikatakan memimpin puncak dari tarekat tersebut adalah seorang Banten Syaikh Abdul Karim murid dari Syaikh Ahmad Khatib Sambas beliau juga menetap di Makkah serta memperoleh kewenangan yang

snagat besar dikalangan orang-orang Banten. Namun Syaikh Abdul karim tersebut tampaknya tidak ada minat dalam masalah politik justru khalifahnya, Haji Marzuki yang diutus dari Makkah ke Banten dikabarkan lebih radikal dan lebih anti-Belanda. ${ }^{55}$

Tahun 1903, Kiay Kasan Mukmin dari Desa Sementara, Sidoharjo (dekat surabaya) memaklumkan dirinya sebagai Mahdi dan memberitahu pengikut-pengikutnya untuk melaksanakan tugas berupa mendirikan sebuah kerajaan baru di Jawa. Kemudian beliau mengajarkan pengikutnya ilmu kedigdayaan serta ia minta pengikutnya untuk berjihad melawan pemerintah Belanda. pertama kali para pemberontak itu bergerak langsung dihabisi oleh pasukan pemerintah yang berhasil menewaskan 40 orang termasuk Kasan Mukmin. Sisa pemberontak ditangkapi, semuanya 83 orang. Pemberontakan ini tidak jauh beda dari sekian banyak pemberontakan mesianistik lain yang senantiasa terjadi di pulau Jawa. Tetapi pemberontakan ini menimbulkan keresahan besar di antara masyarakat Eropa di Surabaya. Desus-desus yang beredar menyatakan bahwa ada rencana pembunuhan terhadap semua warga Eropa, dan dikatakan ahwa pemberontakan akan meluas ke seluruh Jawa. Kemudian penyelidikan-penyelidikan menunjukkan di sana terdapat Naqsyabandi connection. Kiay Kasan Mukmin adalah Khalifah dari Kiay Kasan Tapsir dari Krapyak Lor (dekat Yogyakarta), seorang guru Qadiriyah wa Naqsyabandiyah. Dikabarkan bahwa Kiay dari Krapyak ini telah mendorong Kasan Mukmin untuk melancarkan pemberontakkannya. ${ }^{56}$

Dari kasus di atas benar bahwa tarekat Qadiriyah wa Naqsyabandiyah berfungsi

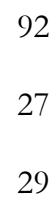

92.

52 Bruinessen, Tarekat Naqsyabandiyah di Indonesia,

53 Parlindungan Siregar, "Perjuangan Rakyat Banten Melawan Belanda: Studi Tentang KH Wasyid," Buletin Al-Turas 23, no. 1 (2017): 55-70.
54 Bruinessen, Tarekat Naqsyabandiyah di Indonesia,

${ }^{55}$ Bruinessen, Tarekat Naqsyabandiyah di Indonesia,

56 Bruinessen, Tarekat Naqsyabandiyah di Indonesia, 
sebagai saluran untuk ketidakpuasan masyarakat terhadap penjajahan. Tarekat tersebut tidaklah antipenjajahan, akan tetapi ia menarik banyak orang-orang yang tidak puas secara politik, dan ia pun menyediakan jaringan komunikasi yang penting. Banyak guru dan anggota tarekat yang terkemuka masuk tarekat, di mana mereka juga mendengar perkembangan politik. Dan pada tahun 1880-an tersebut merupakan periode pergolakan besar-besaran dan pemberontakan. ${ }^{57}$

Dengan berperannya tarekat sebagai pemberantas atas penjajahan dari kolonialisme, maka di sini jelas terlihat bahwa tarekat yang selama ini hanya dianggap tidak dapat mengikuti perkembangan zaman serta hanya berkutik pada masalah spiritualitas saja dan tidak dapat menyelesaikan masalah sosial masyarakat. Seiring berkembangnya zaman tarekat yang dulunya hanya bekutik pada masalah spiritualitas namun melihat persoalan sosial umat mengalami ketertindasan dan penjajahan atas kolonialisme maka tarekatkapun ikut aktif dalam melawan penjajahan. Maka dari itu melihat aksi-aksi yang dilakukan para tarekat Qadiriyah wa Naqsyabandiyah yang kadang hanya menggunakan zikir sebagai kekuatan utama dalam melawan penjajahan. Dan di pimpin langsung oleh para tokoh tarekat itu sendiri, serta mengajari murid-muridnya dengan ilmu supaya berjihad melawana kolonialisme jelas tampak kontribusinya dalam menyelesaikan masalah sosial kehidupan masyarakat. Bukan lagi tarekat yang kuno dan tidak dapat menyeimbangi antara kehidupan spiritual dengan kehidupan sosial akan tetapi tarekat juga dapat memberantas dari jajahan kolonialisme.

Maka dari itu tarekatpun merupakan wahana terbaik untuk melancarkan aksi atas penjajahan dari kolonial. Dan tarekat tersebut adalah alat yang sangat bermanfaat bagi para pemberontak, suatu jaringan organisasi dan jaringan komunikasi. Dan kharisma seorang syaikh tarekat tersebut dapat menjadi aset besar dalam upaya memperoleh dukungan rakyat.

\section{Kesimpulan}

Tarekat tidak hanya difokuskan kepada masalah spiritual saja akan tetapi juga dapat berkontribusi dalam masalah perlawanan dan pemberontakan yang di lakukan oleh kolonial. Dalam melakukan perlawanan tersebut tidak terlepas dari dorongan para tarekat Qadiriyah wa Naqsyabandiyah. Tarekatlah sangat berperan dalam melakukan perlawanan dari kolonialisme yang megecam masyarakat dan ketertindasan yang telah dilakukan oleh para kolonialisme tersebut.

Dalam menjalankan aksinya sebagai pembela dari kolonialisme tidak mudah dilalui oleh para kaum-kaum tarekat. Bahkan banyak memakan korban jiwa, akan tetapi melihat hal tersebut tidak menjadikan para tarekat tersebut akan mundur untuk melawan para kolonialisme, tetapi justru lebih maju untuk melawan dan mempertahankan hak-hak yang dilakukan oleh para kolonialisme terhadap masyarakat dan memperlakukannya semenamena.

\section{Daftar Kepustakaan}

Abdurrahman. Tarekat Qadiriyah Naqsyabandiyah Studi Etnografi Tarekat Sufi di Indonesia. Yogyakarta: Deepublish, 2015.

Ahmadi, Rizqa, and Wildani Hefni. "Mobilitas Mursyid Cum-Aktivis dalam Tradisi Tarekat." Jurnal Theologia 30, no. 2 (2019): 220.

https://doi.org/10.21580/teo.2019.30.2. 3647.

Al-Palimbani, Fadhlail al-Jihad, dalam MMS No CCIX dan V.d.W; Leiden University, F.Or. A 20c

As'ad, Mahrus. "Pengaruh Neosufisme 
Terhadap Perkembangan Tasawuf dan Tarekat Baru." Miqot: Jurnal Ilmu-Ilmu Keislaman, 2016. https://doi.org/10.30821/miqot.v36i1.1 07.

Azis, Ahmad Amir. Teologi Kaum Tarekat. Yogyakarta: Trussmedia Grafiti, 2020.

Azka Fahriza, Muhammad. "Tarekat dan Kultur Perlawanan Islam Indonesia." Siasat Journal of Social, Cultur and Political Studies 3, no. 2 (2019): 46. https://doi.org/10.33258/siasat.v1i2.10.

Bruinessen, Martin Van. Tarekat Naqsyabandiyah di Indonesia. Bandung: Mizan, 1992.

Haris, Didik M Nur, and Rahimin Affandi Abdul Rahim. "Akar Tradisi Politik Sufi Ulama Kalimantan Barat Abad Ke-19 dan 20." Ijtimaiyya: Jurnal Pengembangan Masyarakat Islam 10, no. 1 (2018): 47. https://doi.org/10.24042/ijpmi.v10i1.23 55.

Jannah, Raudatun. "Peran Tarekat Sammaniyah dalam Perang Menteng Melawan Kolonial Belanda di Palembang." Medina-Te: Jurnal Studi Islam, 2017. https://doi.org/10.19109/medinate.v13i 2.3483 .

Kaprabowo, Andi. "Beyond Studies Tarekat Rifa'iyah Kalisalak: Doktrin, Jalan Dakwah, dan Perlawanan Sosial." Jurnal Pemberdayaan Masyarakat: Media Pemikiran dan Dakwah Pembangunan 3, no. 2 (2019): 378.

https://doi.org/10.14421/jpm.2019.03207.

Khanafi, Imam. "Tarekat Kebangsaan: Kajian Antropologi Sufi Terhadap Pemikiran Nasionalisme Habib Luthfie." Jurnal Penelitian 10, no. 2 (2014): 337. https://doi.org/10.28918/jupe.v10i2.367

Ladjal, Tarek, and Benaouda Bensaid. "Sufism and Politics in Contemporary Egypt: A Study of Sufi Political Engagement in the Pre and Post-Revolutionary Reality of January 2011." Journal of Asian and African Studies 50, no. 4 (2015): 471. https://doi.org/10.1177/0021909614534
170.

Malik, Jamal, and Hinnells Jhon. Sufism in the West. New York: New York University Press, 2017.

Mastuki, HS. "Neo-Sufisme di Nusantara Kesinambungan dan Perubahan." Jurnal Kebudayaan dan Peradaban Ulumul Qur'an 6, no. 1 (1997): 51-61.

Miftakhul, Rokhman. "Sejarah Perkembangan Tarekat Qadiriyah wa Naqsabandiyah di Jawa Timur , Pada Masa Kepemimpinan Mursyid KH Mustain Romly 1958-1984." Journal Pendidikan Sejarah 5, no. 3 (2017): 910.

Mikail, Kiki. "Politik dan Perempuan: Perjuangan Politik Perempuan di Iran Pasca Revolusi Islam 1979." Addin 9, no. 2 (2015): 254-55. https://doi.org/10.21043/addin.v9i2.615

Mu'min, Ma'mun. "Sejarah Perkembangan Pendidikan Tasawuf (Studi Tariqah Qadiriyah wa Naqsabandiyah di Kudus Jawa Tengah)." Fikrah 4, no. 1 (2016): 30.

Muedini, Fait. "Sufism and Anti-Colonial Violent Resistance Movements: The Qadiriyya and Sanussi Orders in Algeria and Libya." Open Theology 12, no. 1 (2015): 136. https://doi.org/10.1515/opth-20150003.

Mulyati, Sri. Tarekat-Tarekat Muktabarah di Indonesia. Jakarta: Kencana Prenada Media Group, 2011.

Ni'am, Syamsun. "Tasawuf di Tengah Perubahan Sosial (Studi Tentang Peran Tarekat dalam Dinamika Sosial-Politik di Indonesia)." Harmoni 15, no. 2 (2016): 123-37.

Pinto, Paulo. "Dangerous Liaisons: Sufism and the State in Syria." JIWM Junior Visiting Fellows' Conferences 14, no. 1 (2003): 2.

Ravico, Ravico. "Hubungan Sosial-Politik Tarekat Samaniyah dengan Kesultanan Palembang Darussalam." Islamika: Jurnal Ilmu-Imu Keislaman 18, no. 2 (2019): 26. https://doi.org/10.32939/islamika.v18i0 2.308 . 
Riyadi, Agus. "Tarekat Sebagai Organisasi Tasawuf (Melacak Peran Tarekat dalam Perkembangan Dakwah)." Jurnal AtTaqaddum 6, no. 2 (2014): 359-85.

Saefullah, Asep, and Agus Permana. "AlPalimbani dan Konsep Jihad." Al-Tsaqafa: Jurnal Ilmiah Peradaban Islam 16, no. 2 (2019): 176-87.

Safi, Omid. "Bargaining with Baraka: Persian Sufism, 'Mysticism,' and Pre-Modern Politics." Muslim World 18, no. 1 (2007): 266. https://doi.org/10.1111/j.14781913.2000.tb03691.x.

Siregar, L. Hidayat. "Sejarah, Pemikiran dan Gerakan Politik Tarekat (Mencermati Politik Tarekat Naqsyabandiyah di Indonesia)." Sosio-Religia 8, no. 2 (2009): 140-53.
Siregar, Parlindungan. "Perjuangan Rakyat Banten Melawan Belanda: Studi Tentang KH Wasyid." Buletin Al-Turas 23, no. 1 (2017): 55-70.

"Syair Perang Menteng" ditemukan di situs khastara.perpusnas.go.id dengan catalog ID 220226

Suhayib, Suhayib. "Pemikiran Tasawuf Said Nursi dalam Pemberdayaan Politik (AlTamkin Al-Siyasi) Masyarakat Muslim Turki (Studi Atas Kitab Al-Matsnawi AnNuri)." An-Nida' 38, no. 1 (2013): 60-68.

Suherman. "Perkembangan Tasawuf dan Kontribusinya di Indonesia." Jurnal Ilmiah Research Sains 5, no. 1 (2019): 21.

Syakur, Abd. "Mekanisme Pertahanan Diri Kaum Tarekat." Islamica: Jurnal Studi Keislaman 4, no. 2 (2014): 211. https://doi.org/10.15642/islamica.2010. 4.2.211-228. 